УДК 342.9

DOI https://doi.org/10.32837/pyuv.v0i2(31).577

С. С. Теленик

orcid.org/0000-0002-1328-7595

кандидат юридичних наук

\title{
ПОНЯТТЯ ТА ЗМІСТ ДЕРЖАВНОЇ СИСТЕМИ ЗАХИСТУ КРИТИЧНОЇ ІНФРАСТРУКТУРИ
}

Загальна постановка проблеми. Захисна функція держави була і залишається однією з найголовніших для її існування та розвитку. На кожному історичному етапі у кожній окремій державі ця функція доповнювалася новим змістом, мала свої особливості. Проте сучасність за умов суцільної глобалізації та загострення гібридних війн на тлі стрімкого розвитку технологій значною мірою змінила сутність захисної функції держави. На нашу думку, при іiї реалізації першочергова увага має приділятися саме захисту критичної інфраструктури (далі - ЗКI).

Так, зокрема, В.П. Горбулін відзначив, що РФ продемонструвала світовому співтовариству, що «інфраструктурна війна» є інструментом примусу до врахування інтересів агресора. У цій ситуації важливим чинником забезпечення національної безпеки України стає здатність органів державної влади та суспільства адекватно реагувати на загрози стійкості критичної інфраструктури. Саме у 2014-2015 рр. було вжито низку необхідних кроків у напрямі побудови державної систели захисту інфраструктури життєдіяльності держави та суспільства, які частково дозволили стабілізувати ситуацію [21, с. 352].

Тож виникає нагальна потреба у всебічному теоретичному обгрунтуванні сутності державної системи захисту критичної інфраструктури (далі - ДСЗКІ) насамперед із позицій права.

Аналіз публікацій. Безсумнівна актуальність проблеми зумовлює інтерес до неї вчених не лише різних галузей права, а й різних наук. Тож сьогодні є ціла низка досліджень, присвячених вивченню різних аспектів ЗКІ. Серед них на особливу увагу заслуговують праці таких зарубіжних і вітчизняних науковців, як: J. Baker McNeill, S. Eckert, F. Hoffman, T. Lewis, I. Montanari, Robert T. Marsh, John D. Moteff, Danijella D. Protić, L. Querzoni, Směrnice Rady, J. Ryan, Rand Waltzman, C. Андреєв, Д. Бірюков, Д. Бобро, О. Власюк, С. Гнатюк, О. Глушкевич, С. Гончар, В. Горбулін, О. Довгань, Ю. Дрейс, Д. Дубов, Г. Зубко, В. Євсєєв, О. Єрменчук, В. Заславський, О. Іванченко, С. Кондратов, В. Косенко, В. Ліпкан, В. Лядовська, І. Манжул, В. Петров, М. Рябий, Г. Ситник, О. Суходоля та ін. Особливо слід відзначити внесок авторських колективів Національного інституту стратегічних досліджень, завдяки яким побачили світ монографiї [30], наукові статті [2-5], збірники експертних матеріалів і міжнародних наукових конференцій $[9 ; 12 ; 20]$, численні аналітичні доповіді й записки $[6 ; 15 ; 18]$. Завдяки цьому не тільки розробляється наукове підгрунтя ЗКI, а й формуються засади державної політики у зазначеній галузі. Вкрай важливим є те, що ЗКІ розглядається як комплексна наукова проблема, яка має проекцію на методологічні, політичні, організаційно-правові, інженерно-технічні, кадрові питання.

Виділення не вирішених раніше частин загальної проблеми. Попри значну кількість наукових публікацій із різних аспектів проблеми, котра досліджується, слід визнати, що увага вчених здебільшого зосереджена на політико-управлінській і технологічній складових частинах. Правовий ракурс висвітлений не настільки грунтовно, аби задовольнити наявні потреби суспільства і держави. Звичайно, не можна не згадати про варіант спроби вирішення цих завдань у рамках праці «Зелена книга з питань захисту критичної інфраструктури» [8], в якій подано основні концептуальні засади цього напряму безпекової політики, визначено стратегічні цілі, принципи побудови, суб'єкти та завдання системи захисту KI, а також основні механізми реалізації відповідної державної політики. Утім, ці пропозиції були зроблені з технократичних позицій поза рамками теорії права i юридичної техніки.

На етапі легітимації ключових понять досліджуваної сфери, законодавчого закріплення механізмів діяльності в галузі ЗКІ суттєво актуалізується необхідність узагальнення наявних концепцій і вироблення такої, що надалі стане основою для розроблення відповідних, а головне - ефективних нормативно-правових актів. Це передбачає пріоритетне застосування системного підходу, адже саме він, на мій погляд, якнайкраще дозволяє реалізувати комплексність бачення і подальше формування об'єднаних спільною ідеєю різноманітних концепцій.

Метою статті є визначення і висвітлення поняття та змісту державної системи захисту критичної інфраструктури. Досягнення поставленої мети потребує вирішення таких завдань:

1) встановлення й упорядкування наявних нині поглядів на державну систему захисту критичної інфраструктури;

2) виклад авторської концепції досліджуваного інституту; 
3) формулювання пропозицій щодо удосконалення чинної системи захисту критичної інфраструктури.

Виклад основного матеріалу дослідження. Захист критичної інфраструктури є невід'ємним, можна сказати, одним із найвагоміших елементів національної безпеки держави. Відповідно до Закону України «Про національну безпеку України» ключове поняття, що міститься у назві, тлумачиться як «захищеність державного суверенітету, територіальної цілісності, демократичного конституційного ладу та інших національних інтересів України від реальних і потенційних загроз» [17].

Звертає на себе увагу, що як ключовий елемент трактування законодавець обирає саме «захищеність». По суті це є стан, який досягається внаслідок постійної, цілеспрямованої роботи, а саме захисту. Складність такої діяльності полягає не лише у її безперервності та в постійному удосконаленні, а й у забезпеченні системності, координації, дотриманні єдиних методологічних засад як на локальних, регіональних, галузевих, так і на міжгалузевих рівнях.

Починаючи з 2003 р., від часу проведення у Женеві міжнародного форуму з проблем безпеки, в якому взяли участь представники 28 країн, поступово змінюється концепція ЗКІ. Згідно 3 нею критичну інфраструктуру слід не стільки «захищати», скільки «зміцнювати» і підвищувати «опірність», «стійкість» [31].

Втілення зазначеної тенденції простежується і в матеріалах, які готуються і видаються Національним інститутом стратегічних досліджень. Так, в аналітичній доповіді «Організаційні та правові аспекти забезпечення безпеки і стійкості критичної інфраструктури» вказується, що «в національному законодавстві одних країн вживається термін «захист критичної інфраструктури», а в інших - питання розглядається в широкому контексті, бо мається на увазі безпека та стій$\kappa i c m b$ критичної інфраструктури, що й позначається відповідним терміном» $[15$, с. 8$]$.

Авторська позиція полягає в розумінні, що «захист» Є органічно пов'язаним зі «стійкістю KI». По суті останне можна розглядати як наслідок, як результат доведеного майже до еталонної моделі захисту. Проте, як відомо, ідеалу не існує, але до нього слід прагнути. Це потребує комплексного підходу на всіх рівнях: від всебічного наукового обгрунтування різноманітних аспектів функціонування ДСЗКІ до втілення у практику рекомендацій вчених.

В основі такого комплексного підходу має бути максимально повне осмислення призначення ДСЗKI. Виходячи з основних положень «Концепції створення державної системи захисту критичної інфраструктури», схваленої Кабінетом Міністрів
України [13], виникають підстави констатувати, що ця система слугує принаймні трьом основним напрямам, а саме:

- неухильному забезпеченню гарантованої безпеки, безперебійної життєдіяльності населення, суспільства і держави;

- підтриманню готовності усіх підсистем ДСЗКІ до оперативного реагування на загрози природного, техногенного, антропогенного характеру від попередження, неприпущення до мінімізації наслідків при їх настанні та якнайшвидшого відновлення функцій;

- здійсненню міжнародного співробітництва.

Узагальнюючи, варто підкреслити, що головною метою ДСЗКІ є унеможливлення/мінімізація загроз стратегічно важливим фізичним або віртуальним системам, часткова або повна руйнація яких може спричинити негативні наслідки для безпеки й обороноздатності держави, здоров'я та життедіяльності людей, національної економіки загалом або найбільш вагомих її секторів.

3 позицій права слід враховувати, що на рівні українського законодавства досі немає окремого законодавчого акта, яким би врегульовувалися принципово важливі аспекти ДСЗКІ та взагалі суспільні відносини у сфері інфраструктури.

27 травня 2019 р. до Верховної Ради України був внесений проект Закону України «Про критичну інфраструктуру та її захист» [19]. Проте відповідно до регламенту Верховної Ради, якщо під час діяльності законодавчого органу влади певного скликання проект не був розглянутий, він вважається відкликаним. Через це на нинішньому етапі суб'єкти ЗКІ у своїй діяльності керуються іншими чинними законодавчими актами, які регулюють вказані суспільні відносини опосередковано крізь призму норм безпекового законодавства тощо. Саме ключове поняття «державна система захисту критичної інфраструктури» дотепер не має свого законодавчо закріпленого тлумачення.

Тож, не зважаючи на той факт, що проект Закону «Про критичну інфраструктуру та її захист» залишився без розгляду Верховною Радою України, з позицій науки не забороняється звернення до його концептуальних засад. Зокрема, це стосується визначення досліджуваного поняття, під яким пропонується розуміти систему «суб" $\epsilon \kappa$ тів із забезпечення формування та реалізації державної політики у сфері захисту критичної інфраструктури» [19].

Запропонована дефініція відрізняється від тої, що міститься у «Концепції створення державної системи захисту критичної інфраструктури». Його автори взяли за основу функціональний підхід і визначили ключове поняття як «комплекс організаційних, нормативно-правових, інженерно-технічних, наукових та інших заходів, спрямованих на забезпечення безпеки та стійкості 
критичної інфраструктури» [13], фактично дублюючи визначення, подане в раніше цитованій роботі колективу авторів НІСД [15].

$\mathrm{У}$ такий спосіб застосування формально-юридичного та догматичного методів дозволяє констатувати, що нині паралельно представлено два різні бачення сутності ключового поняття. Кожне 3 них, особливо в теоретичній площині в контексті розвитку адміністративно-правової науки, має право на існування. Проте потреба в операціоналізації цього терміна, його коректного застосування у практичній діяльності зумовлюють ширше застосування системного підходу. Адже саме такий підхід відкриває більше можливостей для розбудови ДСЗКІ, оскільки не обмежується самими тільки заходами.

У цьому зв'язку буде доречним зазначити, що, з позицій загальнонаукової методології, система характеризується структурованістю, ієрархічністю, тісним взаємозв'язком усіх елементів, що входять до неї й об'єднуються на підставі спільної мети $[1 ; 29,11 ; 7]$. Утворюючи єдине ціле, елементи системи спроможні створювати властивості, якими в окремості не наділений жоден з них $[10 ; 14]$.

Проектуючи зазначені положення на досліджуване питання, виявляємо доволі суттєві $\mathbf{m е н -}$ дениії.

3 одного боку, аналіз публікацій засвідчує, що здебільшого вчені віддають перевагу дослідженню різноманітних заходів, які становлять «захист критичної інфраструктури», а не безпосередньо системі ЗКІ. Це призводить до деякої фрагментарності, мозаїчності в описі наукової проблеми. До того ж, вживаючи ключовий термін, дослідники зазвичай уникають його визначення. Причиною цього може бути або хибне уявлення про те, що і без додаткового тлумачення все зрозуміло, або побоювання увійти в суперечності із загальними усталеними, але не легітимізованими поглядами на питання.

3 іншого боку, фахівці Національного інституту стратегічних досліджень від 2012 р. констатують, що «в Україні й досі відсутній системний підхід на національному рівні до управління захистом і безпекою усього комплексу таких систем, з урахуванням їх взаємопов’ язаності» [2, с. 156].

Аналогічна позиція представлена й у вже згаданій «Концепції створення державної системи захисту критичної інфраструктури» [13].

Серед основних проблем, які потребують свого розв'язання, на першому місці у зазначеному документі вказується «відсутність єдиної загальнодержавної системи захисту критичної інфраструктури». Про це зазначається і в рамках чисельних досліджень різноманітних дослідників.

Проте все залишається без змін. Пояснити це можна недостатньою сформованістю уявлень про поняття державної системи захисту критичної інфраструктури й повномірного розуміння механізмів їі діяльності. Тож необхідне створення спочатку наукових, а потім вже і обгрунтованих організаційно-правових засад впровадження і подальшої діяльності ДСЗКІ.

Отже, проект Закону України «Про критичну інфраструктуру та її захист» за своєю базовою концепцією систему, що досліджується, дорівнював системі суб'єктів і відповідно до ст. 14 включав до неї перелік із десяти позицій. Насамперед передбачалося створення уповноваженого органу у сфері захисту критичної інфраструктури, якого нині на сучасному етапі не існує.

До його функцій згідно зі ст. 16 було віднесено:

- координацію діяльності інших суб'єктів;

- взаємодію з операторами ЗКІ;

- оцінку захищеності об’єктів;

- перевірку правильності віднесення об'єктів до критичної інфраструктури;

- оцінку загроз КI на загальнодержавному рівні;

- ведення Національного переліку об’єктів КI України;

- розробку й подання на затвердження Кабінету Міністрів України відповідних документів [19].

Нині ці функції або розпорошені по окремих центральних органах виконавчої влади, або взагалі не здійснюються в належному обсязі. Тож, попри тенденцію до скорочення певних органів влади, існує нагальна потреба у створенні зазначеного суб'єкта, адже від нього великою мірою залежатиме загальний стан ЗКI, а отже, життєдіяльності й обороноздатності держави. Водночас зазначу, що перелічені функції майбутнього органу загалом зорієнтовані на внутрішньодержавний рівень. Проте слід враховувати, що за умов збільшення кількості протиправних проявів за участю транснаціональної злочинності, ведення проти України гібридних війн суттєвого значення набуває організація міжнародної взаємодії з державами-партнерами. Скажу більше: в рамках державно-приватного партнерства потрібно відходити від вузько утилітарного трактування такого партнерства, обмежуючи його лише рамками держави. Він має включати взаємодії з іншими суб’єктами міжнародного права.

Тож у новому проекті Закону України «Про критичну інфраструктуру та їі захист» функиї Уповноваженого органу у сфері захисту критичної інфраструктури мають бути доповнені нормою щодо координації діяльності та підтримання інформаційних зв'язків із відповідними органами інших держав з урахуванням вимог Закону України «Про державну таємницю» [16].

Серед суб'єктів, які входять до ДСЗКІ відповідно до проекту вище зазначеного Закону, на другій позиції у ст. 14 називаються міністерства та інші иентральні органи виконавчої влади. Більш 
деталізовано межі їхньої компетенції та завдання діяльності внормовані:

- у ст. 18 (Міністерство внутрішніх справ України);

- ст. 19 (Центральний орган виконавчої влади, який реалізує державну політику у сфері цивільного захисту);

- ст. 22 (Міністерство оборони України);

- ст. 24 (Центральний орган виконавчої влади, який забезпечує формування та реалізує державну політику в електроенергетичному, ядерно-промисловому, вугільно-промисловому, торфодобувному, нафтогазовому та нафтогазопереробному комплексах, а також забезпечує формування державної політики у сфері нагляду (контролю) у галузях електроенергетики та теплопостачання);

- ст. 25 (Центральний орган виконавчої влади, що забезпечує формування та реалізує державну політику у сферах автомобільного, залізничного, морського та річкового транспорту, надання послуг поштового зв'язку);

- ст. 27 (Центральний орган виконавчої влади, який реалізує державну політику зі здійснення державного нагляду (контролю) у сфері охорони навколишнього природного середовища, раціонального використання, відтворення й охорони природних ресурсів) тощо [19].

Звертає на себе увагу, що проект Закону України виокремлюе сферу діяльності Національної гвардї України (ст. 20) і Національної поліцї України (ст. 21). Враховуючи їхню підпорядкованість, було б логічним при доопрацюванні тексту або включити їхні завдання та межі повноважень до ст. 18 - Міністерство внутрішніх справ України - як окремі пункти, або за нумерацією змістити на 19 та 20 статті відповідно.

Враховуючи вагому роль у ЗКІ Служби безпеки України, укладачі проекту розмістили опис її компетенцій у ст. 17 , тобто одразу після норм діяльності Уповноваженого органу у сфері захисту критичної інфраструктури. На перший погляд, суто з позицій юридичної техніки, може здаватися, що це не відповідає порядку переліку суб'єктів у ст. 14 проекту, оскільки в ньому СБУ представлена на третій позиції. Проте в цьому разі діють не формально-логічні установки, а розуміння того, що саме на Службу безпеки України покладаються найвагоміші завдання з реалізації державної політики у сфері ЗКI, на що я вже звертав увагу у своїх публікаціях.

Окрім вже зазначених суб'єктів, проект Закону, який розглядається, до складу ДСЗКІ включає:

- правоохоронні та розвідувальні органи;

- Збройні Сили України та інші військові формування, утворені відповідно до Законів України;

- місцеві державні адміністраціі;

- органи місцевого самоврядування;

- операторів критичної інфраструктури незалежно від форми власності;
- підприємства, установи й організації незалежно від форми власності, які провадять діяльність, пов'язану із забезпеченням безпеки об'єктів критичної інфраструктури, у т. ч. суб'єкти охоронної діяльності;

- громадські організації, об'єднання й організації роботодавців.

В останньому випадку потребується конкретизація, оскільки не всі громадські організації та інших перелічених суб'єктів можна включати до ДСЗКІ, а тільки тих, хто за сферою своєї діяльності реалізує відповідну державну політику. Позитивною стороною включення до ДСЗКІ окремих юридичних осіб незалежно від форми власності, а також громадських організацій і об'єднань $€$ те, що саме у такий спосіб розкриваються перспективи здійснення державно-приватного партнерства у галузі, що досліджується. Подібна практика на сучасному етапі відповідає усім світовим тенденціям. Про це я писав у своїй статті ще у 2017 p. [27].

Загалом же важливо зазначити, що укладачі проекту Закону для опису ДСЗКІ обрали організаційно-структурний підхід, за якого чітко встановлюються межі компетенції кожного суб'єкта, що входить до складу системи, і саме через опис повноважень встановлюється порядок функціонування системи захисту критичної інфраструктури.

Наголошуючи на нерозривному зв'язку двох нормативно-правових актів (проекту зазначеного Закону і Концепції створення державної системи захисту критичної інфраструктури), з позицій адміністративно-правової науки важливо провести їхній порівняльний аналіз. Це необхідно насамперед для формування узгодженості з майбутнім проектом нового Закону, яким регулюватиметься ЗКІ. Для більшої наочності матеріали доцільно подати у формі табл. 1.

Підводячи проміжні підсулки, слід зазначити, що, незважаючи на різницю у правовому статусі актів, відмінність у їхньому рівні та призначенні поданих документів, роблю науковий висновок $\mathrm{i}$ чітко констатую: за більшістю порівнюваних позицій не фіксується концептуальної єдності.

За нормами юридичної техніки такий документ, як Концепція здебільшого орієнтований на методологічні засади, відтворення способів розбудови діяльності у певному напрямі. Він певною мірою слугує підставою для подальшого створення відповідного Закону України, в якому мають конкретизуватися, деталізуватися норми, закладені в Концепції. Порівняльний аналіз наочно продемонстрував, що подібні положення юридичної техніки витримані неповною мірою. Тож при доопрацюванні проекту або при створенні нового варіанту тексту проекту це слід врахувати. Нині новий проект Закону в галузі захисту критичної інфраструктури має увібрати в себе усе найкраще, 
Порівняльний аналіз основних положень нормативно-правових актів, якими має регулюватися діяльність у сфері ДСЗКІ

\begin{tabular}{|c|c|c|c|}
\hline Критерій порівняння & $\begin{array}{c}\text { Проект Закону України } \\
\text { «Про критичну інфраструктуру } \\
\text { та їі захист» }\end{array}$ & $\begin{array}{l}\text { Концепція створення } \\
\text { державної системи захисту } \\
\text { критичної інфраструктури }\end{array}$ & $\begin{array}{c}\text { Збіг }(+), \\
\text { розбіжність } \\
\text { положень } \\
(-) \\
\end{array}$ \\
\hline Вид акта & Проект Закону & $\begin{array}{c}\text { Розпорядження Кабінету } \\
\text { Міністрів України }\end{array}$ & - \\
\hline Мета документа & $\begin{array}{c}\text { Встановлення принципів і } \\
\text { напрямів розбудови ДСЗКІ, } \\
\text { визначення правових та органі- } \\
\text { заційних засад забезпечення їі } \\
\text { діяльності } \\
\end{array}$ & $\begin{array}{c}\text { Визначення основних напрямів, } \\
\text { механізмів і строків комплексного } \\
\text { правового врегулювання питання } \\
\text { ЗКІ та створення системи держав- } \\
\text { ного управління у сфері ЗКІ } \\
\end{array}$ & - \\
\hline $\begin{array}{l}\text { Вказівка на сферу право- } \\
\text { вого регулювання }\end{array}$ & Сфера національної безпеки & Сфера національної безпеки & + \\
\hline $\begin{array}{l}\text { Домінуючий концепту- } \\
\text { альний підхід до логіки } \\
\text { будови тексту }\end{array}$ & Суб’єктно-об’єктний & Структурно-організаційний & - \\
\hline $\begin{array}{l}\text { Наявність у преамбулі } \\
\text { аргументів щодо необхід- } \\
\text { ності створення ДСЗКІ }\end{array}$ & - & $\begin{array}{c}\text { Вказівка на світові тенденції до по- } \\
\text { силення загроз природного та тех- } \\
\text { ногенного характеру, підвищення } \\
\text { рівня терористичних загроз, збіль- } \\
\text { шення кількості та підвищення } \\
\text { складності кібератак } \\
\end{array}$ & - \\
\hline $\begin{array}{l}\text { Форма тлумачення ключо- } \\
\text { вих термінів }\end{array}$ & $\begin{array}{c}\text { Розташування визначень у } \\
\text { межах першої статті проекту } \\
\text { Закону } \\
\end{array}$ & $\begin{array}{c}\text { Роз'яснення у вигляді вставних } \\
\text { конструкцій по ходу тексту }\end{array}$ & - \\
\hline Тлумачення ДСЗКІ & $\begin{array}{c}\text { Система суб’єктів із забезпе- } \\
\text { чення формування та реалізації } \\
\text { державної політики у сфері ЗКІ }\end{array}$ & $\begin{array}{c}\text { Комплекс організаційних, норма- } \\
\text { тивно-правових, інженерно-тех- } \\
\text { нічних, наукових та інших захо- } \\
\text { дів, спрямованих на забезпечення } \\
\text { безпеки та стійкості критичної } \\
\text { інфраструктури } \\
\end{array}$ & - \\
\hline $\begin{array}{l}\text { Наявність переліку } \\
\text { суб’єктів, що входять до } \\
\text { складу ДСЗКІ }\end{array}$ & Ст. 14 проекту & (n) & - \\
\hline $\begin{array}{l}\text { Позиція щодо Уповнова- } \\
\text { женого органу у сфері ЗКІ }\end{array}$ & $\begin{array}{c}\text { Ст. } 14 \text { - перший у переліку } \\
\text { суб’єктів ДСЗКІ; } \\
\text { Ст. } 16 \text { - розгорнутий перелік } \\
\text { повноважень із дев’яти пунктів }\end{array}$ & $\begin{array}{c}\text { Завдання щодо визначення органу, } \\
\text { відповідального за формування } \\
\text { та реалізацію державної політики } \\
\text { у сфері ЗКІ } \\
\end{array}$ & - \\
\hline $\begin{array}{l}\text { Визначення ролі СБУ } \\
\text { України в ДСЗКІ }\end{array}$ & Ст. 17 , опис із 22 пунктів & Жодної згадки про СБУ & - \\
\hline $\begin{array}{l}\text { Вказівка на держав- } \\
\text { но-приватне партнерство } \\
\text { у ДСЗКІ }\end{array}$ & 5 разів з деталізацією у ст. 36 & 5 разів без деталізації & + \\
\hline $\begin{array}{l}\text { Рівні управління, що } \\
\text { передбачені ДСЗКІ }\end{array}$ & $\begin{array}{c}\text { Загальнодержавний, регіо- } \\
\text { нальний і галузевий, місцевий, } \\
\text { об’єктовий }\end{array}$ & $\begin{array}{l}\text { Загальнодержавний, регіональний } \\
\text { і галузевий, місцевий, об’єктовий }\end{array}$ & + \\
\hline $\begin{array}{l}\text { Пріоритетні сектори } \\
\text { ДСЗКІ }\end{array}$ & $\begin{array}{c}\text { Не виокремлюються, хоча понят- } \\
\text { тя «сектор» застосовується в } \\
\text { тексті } 47 \text { разів }\end{array}$ & $\begin{array}{c}\text { паливно-енергетичний комплекс, } \\
\text { транспорт, мережі життєзабезпе- } \\
\text { чення, телекомунікації та зв’язку, } \\
\text { хімічна промисловість, харчова } \\
\text { промисловість та агропромисловий } \\
\text { комплекс, фінансово-банківський } \\
\text { сектор } \\
\end{array}$ & - \\
\hline $\begin{array}{l}\text { Положення щодо міжна- } \\
\text { родного співробітництва в } \\
\text { галузі }\end{array}$ & $\begin{array}{l}19 \text { разів по тексту, в т. ч.: між- } \\
\text { народні зобов’язання України, } \\
\text { міжнародно-правова допомога, } \\
\text { міжнародно-фінансова допомога, } \\
\text { міжнародна технічна допомога, } \\
\text { міжнародні ініціативи у сфері } \\
\text { кібербезпеки, міжнародні дого- } \\
\text { вори, міжнародні організації, } \\
\text { міжнародна співпраця тощо }\end{array}$ & $\begin{array}{c}5 \text { разів по тексту, саме як «міжна- } \\
\text { родне співробітництво» і } 1 \text { раз - } \\
\text { «міжнародні системи } 3 \text { КІ» }\end{array}$ & - \\
\hline
\end{tabular}


що було розроблено досі, в т. ч. і закордонний досвід, вивченню якого я присвятив також чимало своїх публікацій [22-26; 28].

Переконаний, що насамперед є нагальна потреба дати максимально чітке та повне визначення ключового поняття державної системи ЗКІ. Від його розуміння залежатиме формулювання закладених у законі норм.

Вбачаю, що найбільш доцільним було б трактувати ключове поняття таким чином: державна $\mathbf{c u}$ стема ЗКI - складно організована соціотехнічна систела, призначена для форлування та реалізаиії державної політики у сфері захисту й забезпечення стійкості критичної інфраструктури шляхом застосування уповноваженими суб'єктали взаєлоузгодженого колплексу ефективних управлінських, організаційно-правових, наукових, інженерно-технічних, інформащійних, фінансово-економічних, кадрових та інших заходів.

Прокоментую. Представлене авторське визначення по суті вбирає в себе обидва варіанти тлумачення, запропоновані у порівнюваних до-

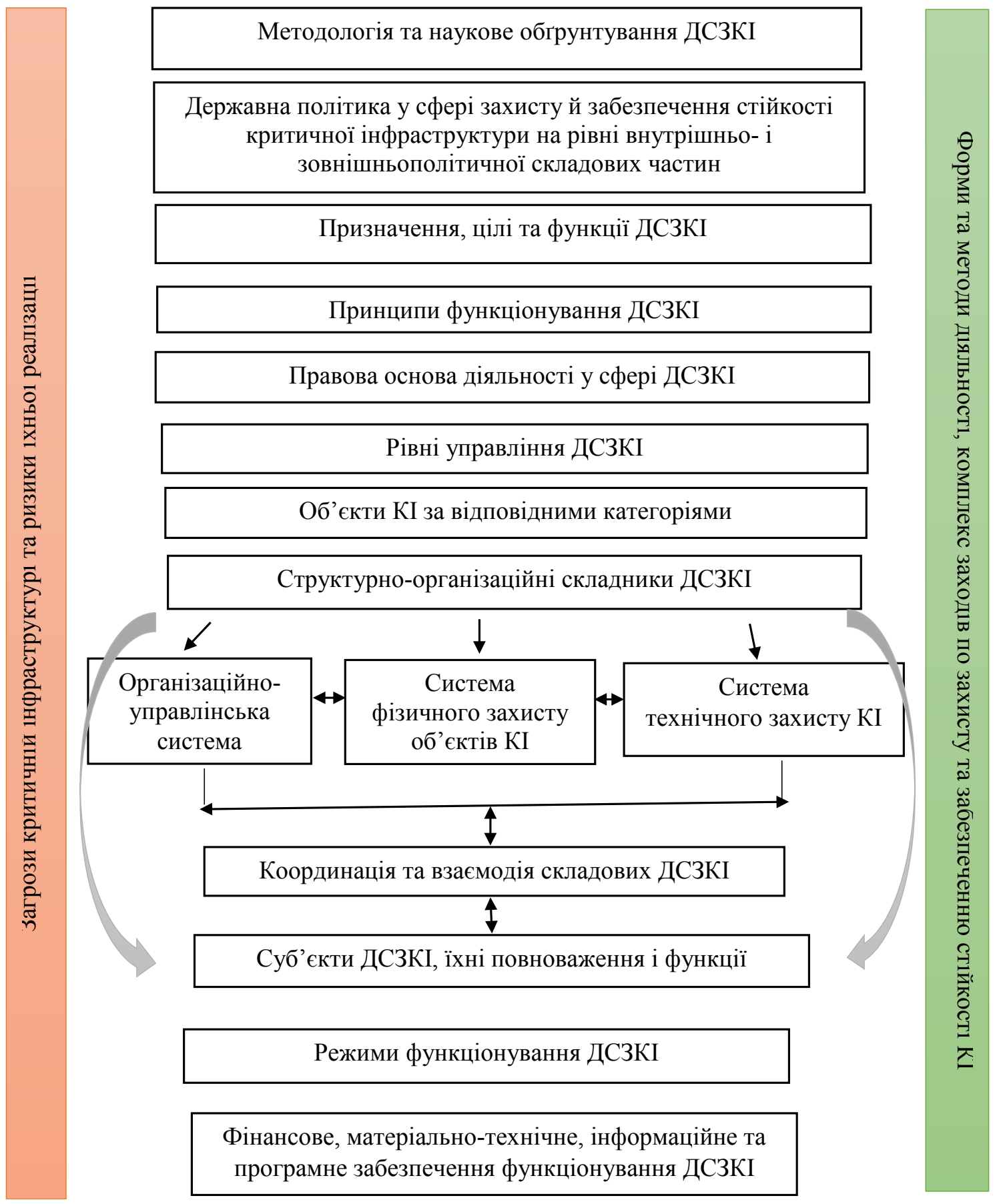

Рис. 1. Сутність державної системи ЗКІ 
кументах. Безумовно, було б не зовсім коректно прирівнювати ДСЗКІ лише до системи суб'єктів, як це зроблено у проекті Закону [19], адже це не тотожні категорії. 3 іншого боку, ДСЗКІ - це не тільки комплекс заходів, як це закарбовано у згаданій вище Концепції [13]. Тож у цій статті науково обгрунтовано та подано на розсуд наукової громадськості винайдений мною компромісний варіант.

Характеристика ДСЗКІ як соиіотехнічної системи грунтується на тому, що вона ставить технологічні здобутки на службу людині, суспільству, державі. Підкреслюється, що така система є складно організованою. 3 позицій методології науки ДСЗКІ має усі ознаки системи систем (макросистеми), адже у їі складі доцільно виділити якнайменше три системи, а саме:

1) організаційно-управлінську систему ЗКI;

2) систему фізичного захисту об’єктів КI;

3) систему технічного захисту КI.

Кожна з представлених систем є багатокомпонентним утворенням зі специфічними цілями й завданнями, що підпорядковуються єдиній меті системи вищого рівня. Кожна 3 них має властиві лише їй засоби, методи та способи діяльності, які мають бути взаємоузгодженими та взаємно доповнюваними. Саме завдяки цьому і досягається ефективність усього комплексу заходів, що вживаються задля забезпечення стійкості критичної інфраструктури.

Подібне розмежування складових систем, що входять до ДСЗКІ, дозволило б уникнути дублювання функцій суб'єктів, максимально чітко визначити сферу діяльності та межі компетенцій кожного з них.

До прикладу. Повноваження Національної гвардї̈ України за представленою концепцією здебільшого знаходяться у системі фізичного захисту об’єктів КI. Водночас такий суб'єкт, як Державна служба спеціального зв'язку та захисту інформації України переважно працює в межах системи технічного захисту КI. Не виключено, що за своїми повноваженнями один і той самий суб'єкт може бути представлений у кожній із систем.

Так, відповідно до чинних нормативно-правових актів на Службу безпеки України покладені функції, які охоплюють усі три зазначені складники ДСЗКІ. Тож перевага подібного підходу полягає ще й у тому, що набуває об'єктивності внесок у справу захисту КI кожного суб’єкта. А це важливо не лише з позицій науки чи управління, а й при обрахуванні видатків коштів державного бюджету на фінансування діяльності саме в аспекті ЗКІ.

Загалом же розкриття поняття та змісту ДСЗКІ на засадах системного підходу найбільш доцільно представити у формі схеми (рис. 1).

Отже, представлена схема наочно демонструє усю складність поняття державної системи ЗКІ в її багатоаспектності. За такого спектру бачення стає зрозумілим, що ДСЗКІ недоцільно зводити лише до системи суб'єктів або комплексу відповідних заходів, а слід розглядати ключове поняття як систему систем (макросистему), яка функціонує у стані постійного розвитку як у реальному, так і у віртуальному просторі.

Висновки. Проведене нами дослідження дозволило встановити, що нинішнім підходам до розуміння сутності державної системи ЗКІ певною мірою бракує системного підходу. Тож при розробці нового проекту Закону України «Про критичну інфраструктуру та їі захист» $€$ можливість при взятті за основу представленої авторської концепції суттєво доповнити, а по окремих положеннях і змінити розуміння ключового поняття. Це має шанси стати суттєвим проривом у справі правового регулювання захисту і забезпечення стійкості критичної інфраструктури.

\section{Jimepamypa}

1. Берталанфи Л. Общая теория систем: обзор проблем и результатов. Систелные исследования : ежегодник. Москва : Наука, 1969. С. 3-25.

2. Бірюков Д.С. Захист критичної інфраструктури в Україні: від наукового осмислення до розробки засад політики. Науково-інфорлаиійний вісник Академії наиіональної безпеки. 2015. Вип. 3-4 (7-8). С. 155-170.

3. Бірюков Д.С. Прийняття політичних рішень щодо захисту критичної інфраструктури. Стратегічні nрiоритети. 2015. № 4 (37). С. 29-34.

4. Бірюков Д.С., Кондратов С.I. Актуальні питання захисту критично важливої для життєдіяльності держави структури. Стратегічні пріоритети. 2011. № 4 (21). С. 113-117.

5. Бірюков Д.С., Кондратов С.І. Стратегія захисту критичної інфраструктури в системі національної безпеки держави. Стратегічні пріоритети. 2012. № 3 (24). C. 107-113.

6. Державно-приватне партнерство у сфері кібербезпеки: міжнародний досвід та можливості для України: аналіт. доповідь / за заг. ред. Д. Дубова. Київ : НІМД, 2018. $84 \mathrm{c.}$

7. Згуровський М.3. Основи системного аналізу. Київ : Вид. група ВHV, 2007. 546 с.

8. Зелена книга з питань захисту критичної інфраструктури в Україні : збірник матеріалів міжнар. експерт. нарад / упоряд. Д.С. Бірюков, С.І Кондратов ; за заг. ред. О.М. Суходолі. Київ : НІСД, 2016.

9. Зелена книга з питань захисту критичної інфраструктури в Україні : збірник матеріалів міжнародних експертних нарад. URL: http://old2.niss.gov.ua/ $\operatorname{articles} / 2213 /$.

10. Климонтович Н.Ю. Без формул о синергетике. Минск : Вышейш. шк., 1986. 243 с.

11. Клир Дж. Системология. Автоматизация решения системных задач / пер с англ. Москва : Радио и связь, 1990.536 с.

12. Концепція захисту критичної інфраструктури: стан, проблеми та перспективи її впровадження в Україні : збірник матеріалів міжнар. наук.-практ. конф. (7-8 листоп. 2013 р., Київ - Вишгород) / Нац. ін-т стратег. досліджень ; упоряд. : Д.С. Бірюков, С.I. Кондратов. Київ : НІСД, 2014. 147 с. 
13. Концепція створення державної системи захисту критичної інфраструктури: затверджено розпорядженням Кабінету Міністрів України від 6 грудня 2017 р. № 1009-р. Урядовий кур’єр. 2018. № 5.

14. Кривцова I.С. Методологічна роль синергетики у порівняльно-правовому пізнанні : автореф. дис. ... канд. юрид. наук : 12.00.01. Одеса, 2008. 20 с.

15. Організаційні та правові аспекти забезпечення безпеки і стійкості критичної інфраструктури України : аналіт. доп. / Д.Г. Бобро та ін. ; за заг. ред. О.М. Суходолі ; Нац. ін-т стратег. дослідж. Київ : НІСД, 2019. $223 \mathrm{c.}$

16. Про державну таємницю : Закон України від 21 січня 1994 р. Відомості Верховної Ради України. 1994. № 16. Ст. 93.

17. Про національну безпеку України : Закон України від 21 червня 2018 р. Голос України. 2018. № 122.

18. Проблеми забезпечення взаємодії при реагуванні на інциденти та кризи комплексного характеру на об'єктах критичної інфраструктури: Аналіт. записка НICД від 07 вересня 2018 p. URL: https://niss.gov.ua/doslidzhennya/nacionalna-bezpeka/ problemi-zabezpechennya-vzaemodii-pri-reaguvanni-naincidenti-ta.

19. Проект Закону України «Про критичну інфраструктуру та їі захист» від 27 червня 2019 р. № 10328. URL: http://w1.c1.rada.gov.ua/pls/zweb2/ webproc4_1?pf $3511=65996$.

20. Протидія тероризму, нерозповсюдження зброї та матеріалів масового знищення й захист критичної інфраструктури : зб. матеріалів засідань Міжвідомчої експертної робочої групи, створеної НІСД / Нац. ін-т стратег. дослідж. ; за ред. О.Д. Маркєєвої, Ю.М. Скалецького. Київ : НІСД, 2013. 101 с.

21. Світова гібридна війна: український фронт : монографія / за заг. ред. В.П. Горбуліна. Київ : НІСД, 2017. $496 \mathrm{c}$.

22. Теленик С. Адміністративно-правове регулювання системи захисту критичної інфраструктури в Icпанії. Актуальні питання розвитку права та законодавства: наукові дискусії : матеріали міжнародної науково-практичної конференції, м. Львів, 15-16 грудня 2017 р. Львів : Західноукраїнська організація «Центр правничих ініціатив», 2017. Ч. 1. С. 120-124.

23. Теленик С. Адміністративно-правове регулювання системи захисту критичної інфраструктури в Італії. Теорія і практика сучасної юриспрудениї : матеріали міжнародної науково-практичної конференції, м. Київ, 7-8 грудня 2018 р. Київ : Центр правових наукових досліджень, 2018. С. 110-112.

24. Теленик С. Адміністративно-правове регулювання системи захисту критичної інфраструктури: досвід Канади. Становлення громадянського суспільства в Україні: норлативно-правове підгрунтя : матеріали міжнародної науково-практичної конференції, м. Дніпро, 4-5 травня 2018 р. Дніпро : ГО «Правовий світ», 2018. C. $123-125$.

25. Теленик С. Державна система захисту інфраструктури: досвід Данії. Актуальні завдання та напрями розвитку юридичної науки у XXI столітті : матеріали міжнародної науково-практичної конференції, м. Львів, 20-21 жовтня 2017 р. Львів : Західноукраїнська організація «Центр правничих ініціатив», 2017. C. 89-91.

26. Теленик С. Державна система захисту критичної інфраструктури: досвід адміністративно-правового регулювання Великої Британії. Актуальні проблели реформування системи законодавства України : матеріали міжнародної науково-практичної конференції, м. Запоріжжя, 25-26 січня 2019 р. Запоріжжя:
Запорізька міська громадська організація «Істина», 2019. С. $87-91$.

27. Теленик С. Державно-приватне партнерство у сфері захисту критичної інфраструктури: адміністративно-правовий аспект. Проблеми вдосконалення правового забезпечення прав та основних свобод людини $i$ громадянина : матеріали міжнародної науково-практичної конференції, м. Запоріжжя, 23-24 червня 2017 р. Запоріжжя : Запорізька міська громадська організація «Істина», 2017.

28. Теленик С. Захист критичної інфраструктури: досвід Нідерландів. Актуальні питання взаєлодї інститутів громадянського суспільства та органів публічного адміністрування у напрялку розвитку правової системи України : матеріали міжнародної науково-практичної конференції, м. Київ, 7-8 вересня 2018 р. Київ : Центр правових наукових досліджень, 2018. C. 102-107

29. Alter S. Work system theory: overview of core concepts, extensions, and challenges for the future. Journal of the Association for Information Systems. 2013. № 14 (2). P. 72-121.

30. Developing The Critical Infrastructure Protection System in Ukraine : monograph / S. Kondratov, D. Bobro, V. Horbulin et al. ; general editor O. Sukhodolia. Kyiv : NISS, 2017. $184 \mathrm{p}$.

31. NARICH R. Infrastructures critiques, continuite des services et cooperation internationale. Defense nat.P. 2003. A.60, N 2. P. 74-84.

\section{Анотація}

Теленик С. С. Поняття та зміст державної системи захисту критичної інфраструктури. - Стаття.

Повноцінне забезпечення національної безпеки неможливе без повноцінного функціонування державної системи захисту критичної інфраструктури. Проте завідсутності чітко визначеногой законодавчозакріпленого розуміння сутності цієї системи, розпорошеності правових норм регулювання діяльності щодо її захисту суттєво знижується ефективність заходів, що вживаються. Стаття має на меті на засадах системного підходу узагальнити погляди на питання та представити авторську концепцію поняття і змісту зазначеної системи.

Автор статті говорить про різницю підходів на рівні «Концепції створення державної системи захисту критичної інфраструктури", затвердженої Наказом Кабінету Міністрів України, та проекту Закону «Про критичну інфраструктуру та її захист». Внаслідок порівняльного аналізу цих документів автор встановлюе, що творці «Концепції» орієнтувалися на функціональний, а проекту Закону - на суб'єктно-об'єктний підхід. Це призводить до того, що «Концепція» інтерпретує ключове поняття через "комплекс заходів», а проект Закону України - через «систему суб'єктів». Дослідник пропонує своє визначення, яке поєднує обидва представлені підходи. На його розуміння, державна система захисту критичної інфраструктури - це складна соціально-технічна система, покликана сформулювати та реалізувати державну політику у сфері охорони та забезпечити стійкість критичної інфраструктури шляхом застосування відповідними суб'єктами комплексу ефективних управлінських, правових, наукових, інженерних, організаційних і кадрових заходів. У візуальній формі сутність концепції представлена у вигляді схеми, яка містить потенціал для значного вдосконалення законодавства.

Ключові слова: критична інфраструктура, захист критичної інфраструктури, державна система захисту критичної інфраструктури, забезпечення стійкості 
критичної інфраструктури, Концепція створення державної системи захисту критичної інфраструктури, юридична техніка нормотворчості, методологія права, структурно-функціональний підхід, системний підхід, теорія систем, макросистема.

\section{Summary}

Telenyk S.S. The concept and content of the state system of the critical infrastructure protection. - Article.

A full-fledged provision of national security is impossible without reliance on the state system of the Critical Infrastructure protecting. However, at the present stage in Ukraine there is no clear, consistent understanding of the essence of this system at the doctrinal level. There is no legislatively fixed interpretation of the key concept. The author of the article notes the difference in approaches at the level of the "Concept of creating a state system of the Critical Infrastructure protection", approved by order of the Cabinet of Ministers of Ukraine, and the draft Law "On Critical Infrastructure and its protection". As a result of a comparative analysis of these documents, the author establishes that the creators of the "Concept" focused on a functional approach, and the draft Law - on a subject-object approach. This leads to the fact that the "Concept" interprets the key concept through the "set of measures", and the draft Law of Ukraine through the "system of subjects". The researcher offers his definition, which combines both presented approaches. In his understanding, the state system of the Critical Infrastructure protection is a complex socio-technical system designed to formulate and implement state policy in the field of protection and ensure the sustainability of the Critical Infrastructure through the application by the relevant entities of a complex of effective managerial, legal, scientific, engineering, organizational and personnel measures. In a visual form, the essence of the concept is presented in the form of a scheme that contains the potential for a significant improvement in legislation.

Key words: critical infrastructure, critical infrastructure protection, ensuring the sustainability of critical infrastructure, state system of the critical infrastructure protection, concept of creating a state system of the critical infrastructure protecting, legal rulemaking techniques, legal methodology, structural and functional approach, system approach, systems theory, system of systems. 